6. Ministry of Health Israel. Two-dose vaccination data. Government of Israel; 2021. https://www.gov.il/BlobFolder/reports/vaccineefcacy-safety-follow-upcommittee/he/fles publications corona_twodose-vaccination-data.pdf. Truy cập ngày $30 / 11 / 2021$.

7 S. V. Subramanian. Akhil Kumar. Increases in COVID-19 are unrelated to levels of vaccination across 68 countries and 2947 counties in the United States. https://link.springer.com/ article/10.1007/s10654-021-00808-7. Truy cập ngày 29/11/2021.
8. McMorrow M. (rep.). Improving communications around vac cine breakthrough and vaccine efectiveness. 2021. Retrieved from https://contextcdn.washingtonpost.com/notes/prod/default/ documents/8a726408-07bd-46bd-a9453af0ae2f3c37/note/57c98 604-3b54-44f0-8b44b148d8f75165. Truy cập ngày 30/11/2021.

9 Mark

w. Tenforde, Wesley H. Self, Katherine Adams. Association Between mRNA Vaccination and COVID-19 Hospitalization and Disease Severity. https://jamanetwork. com/journals/jama/fullarticle/2786039. Truy cập ngày $30 / 11 / 2021$.

\title{
KẾT QUẢ QUẢN LÝ, ĐIỀU TRI NGƯờI BÊNNH BỊ TĂNG HUYẾT ÁP TẠI TRUNG TÂM Y TẾ HUYẾN GÒ CÔNG TÂY, TỈNH TIỀN GIANG GIAI ĐOẠN 2019 - 2020
}

\section{TÓM TẮT}

Đắt vấn đề: Điều trị Tăng huyết áp (THA) là công việc liên tục và lâu dài nên viêc quản lý và điêu trì người bệnh THA là hết sức cần thiết. Mục tiêu: Đánh giá kết quả quản lý điều trị người bệnh THA và phân tích một số yếu tố ảnh hưởng đến kết quả quản lý điều trị THA tại Trung tâm y tế huyện Gò Công Tây từ năm 2019- 2020.Phương pháp: Ṅghiên cứu mô tả cắt ngang kết hợp giữa định lượng và định tính dựa trên cơ sở thu thập thông tin từ phần mềm quản lý, phỏng vấn sâu cán bộ y tế và thảo luận nhóm bệnh nhân THA được quản lý tại TTYT huyện Gò Công Tây từ tháng 4 đến tháng 10/2021.Kết quả: Số người mắc THA được khám và điêu tri ngày càng tăng hàng năm, tỉ lệ người bệnh đi tái khám đúng lịch là $63,6 \%$. Tỉ lệ người bệnh dùng thuốc đúng liều là $89,3 \%$. Kết điêu trị có $28,9 \%$ đối tượng đạt huyết áp mục tiêu. Các chính sách, quy định về quản lý và điêu trị THA, sự thiếu hưt nhân lực, hạn chế về trang thiết bị, cơ sớ vầt chất và thuốc của TYYT, không có nguồn kinh phí hoạt động, cùng các yếu tố cá nhân của người bệnh là những yếu tố ảnh hưởng đến công tác quản lý điều trị THA. Kết luận: Tỷ lệ bệnh nhân đạt huyết áp mục tiêu còn khá thấp $(28,9 \%)$, có nhiều yếu tố từ phía cớ sở y tế và người bệnh ảnh hưởng đến công tác quản lý, điều trị THA.

Từ khóa: Tăng huyết áp, huyết áp mục tiêu, quản lý, điều trị, Gò Công Tây.

\section{SUMMARY \\ ASSESSMENT OF THE RESULTS OF THE TREATMENT MANAGEMENT OF PERSONS WITH}

\footnotetext{
${ }^{1}$ Trung tâm Y tế huyện Gò Công Tây,

2Trường Đai hoc Y tề công cộng

Chịu trách nhiệm chính: Phạm Văn Quang

Email: quangphamgct1965@gmail.com

Ngày nhận bài: 20.9.2021

Ngày phản biên khoa hoc: 12.11.2021

Ngày duyệt bài: 23.11.2021
}

Phạm Văn Quang1, Trần Quốc Lâm²

\section{HIGH BLOOD PRESSURE AT THE HEALTH CENTRAL OF GO CONG TAY DISTRICT, TIEN GIANG PROVINCE FOR 2019 - 2020}

Background: Treatment of hypertension is a continuous and long-term work, so the management and treatment of hypertensive patients is essential. Objectives: Evaluation of the results of management and treatment of hypertension patients and analysis of some factors affecting the results of treatment and management of hypertension at Go Cong Tay District Medical Center from 2019 to 2020. Methods: A crosssectional descriptive study combining quantitative and qualitative based on information collection from management software, in-depth interviews with medical staff and group discussion of hypertensive patients managed at the Go Cong Tay district health center from April to October 2021.Results: The number of people with high blood pressure being examined and treated is increasing every year, the rate of patients coming back for follow-up examination on schedule is $63.6 \%$. The rate of patients taking the correct dose was $89.3 \%$. As a result of treatment, $28.9 \%$ of subjects reached the target blood pressure. Policies and regulations on management and treatment of hypertension, shortage of human resources, limitations on equipment, facilities and drugs of $\mathrm{CHS}$, no operating funding, and personal factors of patients are factors affecting the management of hypertension treatment.Conclusion: The percentage of patients reaching the target blood pressure is still quite low, there are many factors from the medical facilities and the patients that affect the management and treatment of hypertension.

Keywords: Hypertension, target blood pressure, management, treatment, Go Cong Tay.

\section{I. ĐĂT VẤN ĐỀ}

Tăng huyết áp là bệnh mạn tính, đòi hỏi người bệnh phải kiên trì điều trị và tuân thủ chế độ điều trị nếu không sẽ có thể mắc nhiều biến 
chứng, trở thành gánh nặng cho gia đình và xã hội. Vì thế tuân thủ trong điều trị tăng huyết áp của người bệnh là vô cùng quan trọng. Tại Trung tâm $Y$ tế Gò Công Tây, chương trình quản lý điều tri tăng huyết áp còn nhiều hạn chế, Trung tâm có nhiêu khó khăn về nhân lực, trang thiết bị y tế và bác sĩ chuyên khoa về tim mạch còn hạn chễ. Đồng thời, tại Gò Công Tây chưa có các nghiên cứu liên quan về vấn đề này, vấn đề đặt ra là thực trạng công tác quản lý kết quả điều trị người bệnh bị THA tại Trung tâm hiện nay như thế nào? Quá trình triển khai thực hiện có những yếu tố nào ảnh hưởng đến kết quả quản lý điều trị? Việc đánh giá kết quả của công tác này có đáp ứng được mục tiêu đề ra hay không? Vì những lý do nêu ở trên, nghiên cứu: "Đánh giá kết quả quản lý điều trị của người bệnh bị tăng huyết áp tại Trung tâm Y tế huyện Gò Công Tây, tỉnh Tiền Giang giai đoan 2019 - 2020" được thực hiện nhằm đánh giá kết quả công tác quản lý, điều trị bệnh nhân THA và những kiến nghị chính sách phù hợp để cải thiện và nâng cao chất lượng công tác này.

\section{II. ĐỐI TƯƠ'NG VÀ PHƯƠNG PHÁP NGHIÊN CỨU Đối tượng nghiên cứu:}

Cấu phần định lượng: Chọn tất cả những bênh nhân THA đến khám và điều trị có sổ khám bểnh và toa thuốc lưu ở phần mềm khám chữa bểnh của Trung tâm $Y$ tế Gò Công Tây. Loại trừ: Bệnh nhân dưới 18 tuổi, bệnh nhân đang mang thai.

Cấu phần định tính: Bác sỹ và điều dưỡng KCB trực tiếp cho người bệnh THA và bênh nhân THA đang được quản lý tại TTYT Gò Công Tây. Tiêu chuẩn loại trừ: Bệnh nhân không đủ sức khỏe trả lời phỏng vấn, người bị rối tâm thần, đang mang thai và bệnh nhân dưới 18 tuổi.

Phương pháp nghiên cứu: Mô tả cắt ngang có phân tích

Cỡ mẫu định lượng:

$$
n=\frac{Z_{1-\alpha / 2}^{2} \cdot p(1-p)}{d^{2}}
$$

Trong đó, Z: trị số từ phân phối chuẩn (với độ tin cậy $95 \%, z=1,96) ; d$ : sai số tối đa cho phép, dự kiến 7\%; Giá trị $\mathrm{p}$ được tham khảo từ nghiên cứu của Nguyễn Công Bằng (2018) [2], giá trị $p=56,5 \%$ là tỷ lệ người bệnh đạt huyết áp mục tiêu. Tính được cỡ mẫu là: 196 người. Dứ trù 20\% đối tượng từ chối tham gia thì cõ mẫu thành 220 người. Thực tế thu thập thông tin 225 bệnh nhân từ phần mềm quản lý.

Cỡ mẫu định tính: Người cung cấp dịch vụ, phỏng vấn sâu 01 Lãnh đạo TTYT, 01 Lãnh đạo
Khoa Khám bênh, 01 Bác sỹ khám và 01 Điều dưỡng trực tiếp quản lý, theo dõi, cập nhật thông tin của người bệnh THA trên phần mềm quản lý khám bệnh tại TTYT. Người sử dụng dịch vụ: Thảo luận nhóm 2 nhóm đối tượng: Nhóm thường xuyên đến khám điều trị tại Trung tâm và nhóm không thường xuyên đển khám điêu trị tại Trung tâm. Tổng số là 24 người tham gia, mỗi nhóm 14 người.

Xử lý, phân tích số liệu: Số liệu định hượng được tổng hợp và mô tả dạng tần số, tỉ lệ \%, đối với các dữ liệu rời rạc khác sẽ được so sánh với các tiêu chuẩn liên quan về quản lý và điều trị THA.

\section{KẾT QUẢ NGHIÊN CứU}

Thực trạng quản lý, điều trị bệnh nhân THA tại Trung tâm $Y$ tế Gò Công Tầy

Tình hình bệnh nhân THA điều trị tại TTYT trong hai năm 2019, 2020: Trong năm 2019, có 3221 bệnh nhân THA đến khám và điều trị, trong đó nam chiếm $51,8 \%$ và nữ chiếm $48,2 \%$. Độ tuổi trên 65 tuổi chiếm tỉ lệ cao nhất với 55\%; kế đó là nhóm từ 40 đến 65 tuổi chiếm $41 \%$ và thấp nhất là nhóm dưới 40 tuổi $4 \%$. Trong năm 2020, có 3671 bệnh nhân THA đến khám và điều trị, trong đó nữ chiếm $47,2 \%$ và nam chiếm $52,8 \%$. Độ tuổi trên 65 tuổi chiếm tỉ lệ cao nhất với $53,6 \%$; kế đó là nhóm từ 40 đển 65 tuổi chiếm $43,9 \%$ và thấp nhất là nhóm dưới 40 tuổi chiến 2,5\%. Số lượt người bệnh đến khám THA năm 2019 là 14.098 lượt và năm 2020 là 17.921 lượt.

Về tình hính quản lý, điều trị: Trong số 225 hồ sơ bệnh án chọn ngấu nhiên hệ thống, phần lớn bệnh nhân phát hiện mình THA khi đến khám bệnh tại TTYT với tỉ lệ 63,6\%. Tần suất tái khám của người bệnh 1 tháng/lân chiếm tỉ lệ cao nhất với 38,7\%; tỉ lệ đi khám định kỳ 2 tháng/lần chiếm 19,6\%; khám định kỳ 3 tháng/lân chiếm $14,2 \%$. Vấn còn $27,6 \%$ đối tượng không tái khám định kỳ vào thời gian xác định. Tî lệ người bệnh đi tái khám không đúng lịch cũng chiếm tỉ lệ tương đối cao là $36,4 \%$. Tỉ lệ người bệnh dùng thuốc đúng liều và đều đặn chiếm tỉ lệ khá cao với $89,3 \%$. Dù vậy, vấn còn $10,7 \%$ chưa tuân thủ đúng việc dùng thuốc đúng và đều. Kết cục, trong 225 bênh nhân ngoại trú chỉ có 28,9\% đạt được huyết áp mục tiêu.

2. Một số yếu tố ảnh hưởng đến hoạt động quản lý và điêu trị tăng huyêt áp

Chính sách, quy định về quản lý và điều

trị THA: Trong những năm qua, Bộ Y tế đã ban hành các văn bản hướng dẫn thực hiện chương trình phòng chống THA cũng như trong công tác chẩn đoán điều trị, tự đó góp phần đáng kể 
trong việc nâng cao hiệu quả công tác quản lý, điều trị. Trong thực tế, bác sĩ điều trị cũng bị giới hạn bởi nhiều quy định của nhà nước cũng như áp lực chỉ tiêu của đơn vị: "Mình làm cũng bị chi phối nhiều quy định, cứng lẫn mềm, có khi phải khai thác kỹ thông tin, bệnh xấu hoặc nếu người bệnh có đều kiện đi lại thì cho đơn thuốc $10-15$ ngày, chứ không phải ai cũng cho đơn thuốc 1 tháng, nếu ai cũng hẹn một tháng thì cuối năm không đạt chỉ tiêu nghị quyết hội nghị cán bộ viên chức" - PVS Bác sĩ điều trị.

Nhân lực y tế: Một trong những bất cập trong công tác quản lý điều trị là bệnh nhân vẫn ưu tiên đến TTYT khám bệnh, dù đã được tư vấn giới thiệu về TYT tái khám. Sở dĩ có tình trạng này, một phần la do nhân lực tại TYT còn thiếu, kiêm nhiệm nhiều việc, bệnh nhần thường không được phụ vụ chu đáo nhất, kết quả phỏng vấn định tính đã phản ánh: "Tôi đi thẳng lên huyện cho yên tâm, khám rồ lĩnh một bịt thuốc bự, vào TYT xã có khi không có bác sĩ, phải đợi, nhiều khi khám xong lại có mấy viên thuốc, còn lại kêu mình ra quầy thuốc mua thêm, rắc rối, mất công quá" - TLN Người bệnh.

Kinh phí hoạt động: Chương trình tăng huyết áp quốc gia không còn cấp kinh phí hoạt động cho tuyến huyện. Mọi hoạt động tiến hành như công việc thường quy với kinh phí chi chung cho các hoạt động y tế tại cả trung tâm y tế. Vì vậy, một sổ hoạt động truyền thông tư vấn, sàng lọc cũng bị giới hạn hoặc không thể thực hiện. "Hằng năm, chúng tôi đều lên kế hoạch triển khai thực hiện chương trình phòng, chống THA tại huyện nhưng vì không có kinh phí hoạt động nên các hoạt động truyền thông về phòng, chống bênh THA còn han chế về số lượng và hình thức, dẫn đến người dân chưa thật sự hiểu được tầm quan trong của công tác điều trị khi mắc THA để kiểm soát huyết áp và dự phòng biến chứng" - PVS Lãnh đạo TTYT.

\section{Các yếu tố từ người bệnh:}

Điều kiến kinh tế: nhiều bệnh nhân gia đình khó khăn, họ không có điều kiện mua máy đo huyết áp để tự theo dõi chỉ số huyết áp tại nhà, nên không theo dõi được huyết áp của họ. Cũng có những trường hợp, người bệnh có biển chứng, phải chuyển điêu trị nội trú nhưng gia đình không có điều kiện chi trả nên họ xin về nhà, từ đó TTYT cũng gặp tình huống khó xử. "Tiền đâu mà mua máy chú ơi, giờ già cả rồi có làm gì ra tiền đâu, xin tiền con cháu uống thuốc thôi" - TLN Người bệnh. Một ý kiến khác: "Giờ mua cái BHYT gần cá triệu, tiền ăn cả tháng đó chú, bệnh thì chịu chứ nhiều lúc cũng lo, khi nào nặng đi rồi tính" TLN người bệnh.

Số năm mắc bệnh: những người mắc bệnh đã nhiêu năm, họ cho thấy việc tuân thủ thực hành là rất tốt, điều này giúp gợi ý trong việc thành lập các nhóm đồng đẳng, các câu lạc bộ THA để những người đi trước chia sẽ cho những người mắc mới: "Tui bị nay cũng 8 năm rồi, bệnh này phải kiêng cử nhiều thứ, đặc biệt là phải tái khám đúng lịch và uống thuốc đều, uống riết thành thói quen, với lại ngày nào tui cũng tập thể dục hết, bỏ thuốc bỏ rượu luôn, thấy khỏe bình thường, do mình thôi, bệnh thì phải lo chứ" - TLN Ngưới bệnh.

Kiến thức phòng bệnh: Người bệnh còn nhầm lẫn trong việc điều trị, họ đã bỏ thuốc sau khi đạt huyết áp mục tiêu, đây là một sai lầm, mà xuất phát từ nhiều phía, có thể do công tác truyền thông tư vấn chưa đề cập hoặc sự chủ quan của người bệnh: "Nhiều bệnh nhẩn sau khi đạt huyết áp mục tiêu, họ nghỉ mình đã khỏi bệnh nên không uống thuốc, không tái khám nữa, cái đó là sai, và một số người bệnh mình đang hiểu sai vấn đề" - PVS Điều dưỡng phụ trách.

Thực hành điều trị: Một yếu tố tiếp theo thuộc về cá nhân người bệnh ảnh hưởng đến công tác quản lý đó là thực hành quy trình quản lý hay là thực hành điều trị THA của chính người bệnh. "Có khi người bệnh không tái khám luôn, rồi không biết họ có đi khám ở đâu không, cũng không biết họ còn uống thuốc không, không đến thì mình không thể biết tình trạng họ như thế nào, lâu lâu cũng có trường hợp biến chứng rồi mới đến, mình cũng hỏi họ nói khám biết THA rồi tự mua thuốc uống" - PVS Điều dưỡng phụ trách.

Khả năng tiếp cận dịch vụ: Khả năng tiếp cận nơi cung cấp dịch vụ bị hạn chế, một số người bệnh tự mua thuốc uống, họ không đến TYT hay TTYT, điều này làm cho số ca mắc nằm trong cộng đồng không được quản lý. "Hôm nay tui nghe nói máy chú huyện xuống nên tui tới khám, chứ thường ghé tiệm thuốc tây mua à, già cả rồi đi tới đi lui bất tiện lắm" - TLN Người bệnh. Cũng có trường họp người bệnh lấy đơn thuốc cũ tự đi mua thuốc về uống, dù là đơn của bác sĩ, nhứng việc làm này cũng có những hạn chế, vì tình trạng bệnh sẽ thay đổi trong quá trình điều trị, tự điều trị sẽ mất đi vai trò của thầy thuốc trong khâu tư vấn, giáo dục sức khỏe về THA: "Bữa nào hết thuốc mà kẹt công chuyện hay mua gió gì đó thì tui cầm sổ khám bệnh đi mua ở quầy thuốc gần nhà luôn, thì cũng uống thuốc của bác sĩ cho mà" -TLN Người bệnh. 


\section{BÀN LUÂN}

Tình hình bênh nhân THA điêu trị ngoại trú trong giai đoạn 2019-2020. Người bệnh đến tái khám năm sau cao hơn năm trước, tỷ lệ nam cao hơn nữ, lứa tuổi hay gặp là từ 40 đến 65 tuổi. Độ tuối và giới của người bệnh trong nghiên cứu này tương đương với nghiên cứu của Nguyễn Thị Đào Hương tại Tam Đảo, Vĩnh Phúc [7]. Số lượt khám tăng huyết áp năm sau cao hơn năm trước điều này cũng phù hợp vì THA là bệnh toàn thân có thể có nhiều biến chứng tổn thương cơ quan đích, đồng thời số lượt khám tăng hơn so với bệnh đến khám vì THA, do những bệnh khác kèm theo.

Hoạt động quản lý và điêu trị tăng huyêt áp

Phát hiện bênh mới: Qua kết quả phân loại, chúng tôi nhận thấy phần lớn bệnh nhân phát hiện mình THA khi đến khám bệnh tại Trung tẩm $Y$ tế với tỉ lệ $63,6 \%$, còn lại $36,4 \%$ cho biết phát hiện bị THA khi tham gia chiến dịch khám sàng lọc. Như kết quả phần phỏng vấn định tính, cán bộ y tế cho biết hầu như chủ trương thông tuyến bảo hiểm y tế đã tạo điều kiện cho người dân tự do chuyển từ TYT lên TTYY mà không cần thông qua TYT. Bên cạnh đó, người dân vẫn tin tưởng chất lượng dịch vụ ở cơ sở tuyến trên hơn, trong đó có vấn đề thuốc điều trị, trang thiết bị xét nghiệm, chẩn đoán. Kết quả của chúng tôi cũng tương tự nghiên cứu của Lê Kim Việt tại Tuyên Quang, trong nghiên cứu của tác giả này, người dân chuyển lên tuyến trên vì TYT xã không cung ứng đủ thuốc điều trị [6].

Vấn đề tái khám định kỳ của người bệnh: Theo thống kê, vẫn tồn tại 27,6\% đối tượng tái khám không theo thời gian xác định. Kết quả này đòi hỏi ngành y tế cần xem xét cẩn thận, vì đây là một lố hỏng khá lớn, việc "chập chờn" về số liệu quản lý giữa huyện và xã vô tình làm chúng ta bỏ sót những đối tượng nguy cơ cao, mà đển khi họ tìm đến cơ sở y tế thì đã trở nặng.

Vấn đề tái khám đúng lịch hen: Tỉ lệ người bệnh đi tái khám không đúng lịch cũng chiếm tỉ lệ tương đối cao là 36,4\%. Kết quả của chúng tôi cao hơn của Nguyến Công Bẳng tại Đồng Tháp với 12,6\% [2]. Lý giải cho tình trạng trên có một số nguyên nhân do thói quen của người dân chỉ đi khám khi khó chịu hoặc khi có biến chứng của bệnh; do nhận thức, dân trí, thiếu thông tin về bệnh; do thủ tục hành chính... khiến bệnh nhân điều trị không điều trị hoặc điều trị từng đợt. Điều này dẫn đến đa số không điều trị thường xuyên, liên tục để kiểm soát huyết áp và dự phòng biến chứng. Tương tự như tổng kết của Hội Tim mạch Việt Nam (2006) có $15 \%$ người bệnh biết mình có bệnh THA nhưng không điều trị, $15 \%$ người bệnh điều trị thất thường, không đúng cách [1].

Vấn đề tuân thủ dùng thuốc: Vẫn còn 10,7\% chưa tuân thủ đúng việc dung thuốc đúng và đều. Kết quả này tương tự nghiên cứu của Nguyễn Công Bằng tại Sa Đéc, Đồng Tháp với $11,4 \%$ chưa tuân thủ việc dùng thuốc [2]. Đối với người bị THA, quan trọng nhất cần làm là kiểm soát chỉ số huyết áp và cần tuân thủ chặt chẽ quy trình điều trị. Vì vậy, thuốc rất quan trọng trong việc duy trì mức huyết áp để giảm nguy cơ đau tim, đột quy. và giảm mức trầm trọng của bệnh.

Về tỉ lề bênh nhân đạt huyêt áp muc tiêu: Trong 225 bênh nhân ngoại trú chỉ có $28,9 \%$ đạt được huyết áp mục tiêu. Kết quả này cao hơn nghiên cứu của Nguyễn Thị Dự $(20,4 \%)$ [5] nhưng thấp hơn nghiên cứu của Nguyễn Công Bằng tại tỉnh Đồng Tháp $(56,5 \%)$ [2]. Trong phần phỏng vấn định tính, nhiều ý kiến về việc bệnh nhân tự mua ở các quầy dược tư nhân, mua theo toa cũ mà không đến tái khám, điều này có thể là một trong những nguyên nhân khó đưa chỉ số huyết áp về giá trị mục tiêu.

Một số yếu tố ảnh hưởng đến hoạt động quản lý và điêuu trị Tăng huyết áp

Các chủ trương, chính sách, quy định về quản lý và điều trị THA: Thứ nhất, các yếu tố khách quan, chi phối bởi các cơ quan cấp trên, điều này điển hình như Luật Bảo hiểm xã hội sửa đổi bổ sung năm 2016, việc thông tuyến huyện đã tạo điều kiện cho bệnh nhân đi thẳng lển TTYT huyện mà không thồng qua TYT để chuyển tuyến, điêu này dẫn đến lỗ hỏng quản lý ca mắc. Nghị định số 105/2014/ND-CP ngày 15/11/2014 của Chính phủ quy định chi tiết và hướng dẫn thi hành một số điêuu của Luật BHYT; Theo thông tư 15/2018/TT-BYT ngày 30 tháng 05 năm 2018; Quyết định số $1208 / Q \oplus-T T g$ ngày 04/9/2012 của Bộ Y tế về việc ban hành kế hoạch phòng, chống bệnh không lây nhiễm giai đoạn 2015-2020, Quyết định số: 2559/QĐ-BYT Ban hành kế hoạch tăng cường thực hiện điều trị, quản lý y học gia đình tại các trạm y tế xã, phường, thị trấn giai đoạn 2018-2020.

Nhân lực làm công tác y tê: Tình trạng cập nhật kiến thức mới của đội ngũ y bác sĩ về THA cũng chưa thường xuyên, dù TTYT cung cấp thông tin tỉ lệ cập nhật kiến thức đạt 63,7\% nhưng có vẻ như các kiến thức của họ là không mới. Thiết nghĩ, trong thời gian tới TTYT nên chú trong đến công tác đào tạo liên tục nói chung và 
chuyên sâu về THA nói riêng cho viên chức phụ trách quản lý điều trị. Các hình thức có thể nghĩ đến là đảo tạo trực tuyến, mời giảng viên về địa phương đào tạo lại cho mạng lưới THA của huyện để phục vụ tốt cho công tác điều trị, nhất là các trường hợp có biến chứng.

\section{Các yếu tố thuộc về người bệnh}

Điều kiện kinh tế: Trong phẩn nghiên cứu định tình về vấn đề này, chúng tôi ghi nhận một số trường hợp điều kiện kinh tế khó khăn, việc mua máy đo huyết áp tại nhà hoặc mua BHYT đối với họ là cả một vấn đề lớn cần đắn đo. Kết quả nghiển cứu của chúng tôi cũng tương tự của tác giả Đào Thị Nguyễn Hương, tình trạng kinh tế hay mức thu nhập của người bệnh có liên quan đến việc sử dụng dịch vụ khám chữa bệnh THA tại cơ sở y tế [8].

Sồ năm mắc bệnh: Kết quả của chúng tôi cũng tương tự của Đào Thị Nguyễn Hương (2016), theo tác giả này, người mắc THA trên 1 năm sẽ tuân thủ điều trị tốt hơn 7,3 lần so với người mắc dưới 1 năm [7]. Áp dụng khuyến nghị từ nghiên cưu của Nguyễn Hữu Đức trong nghiên cứu kiến thức, thực hành tuân thủ điều trị tăng huyết áp của hội viên câu lạc bộ bệnh nhân tăng huyết áp bệnh viện Bạch Mai [3], chúng tôi nhận thấy rằng, để giảm thiểu áp lực cho cán bộ y tế, cần thiết nên có những câu lạc bộ chia sẽ kinh nghiệm về tuân thủ điêu trị tại nhà giữa những bệnh nhân THA, những người mắc bệnh lâu năm sẽ là những "tư vấn viên" để chia sẽ thực tế về quá trình điều trị của họ.

Kiến thức, thái độ và thức hành điều trị: Qua kết quả phỏng vấn sâu các bệnh nhân bị THA cho thây sự hiểu biết và chấp hành điều trị nghiêm túc theo khuyến cáo về chẩn đoán và điêu trị, dự phòng THA của người bệnh không rõ ràng. Kết quả của chúng tôi cũng tương tự công bố của Nguyễn Thị Ánh Tuyết trong một nghiên cứu tại Cao Bằng [4].

Khả năng tiếp cận dịch vụ: Những yếu tố thuộc về người bệnh, các lý do như nhà xa cơ sở y tể, vấn đề già yếu, khó khăn trong đi lại,... là những nội dung được bệnh nhân nhắc đến về việc khó tiếp cận dịch vụ quản lý, điều trị THA. Thực trạng hoạt động như hiện nay khó có thể đạt được mục tiêu trong Quyết định số 1208/QĐ-TTg ngày 04/9/2012 của bộ y tế về việc ban hành kế hoạch phòng, chống bệnh không lây nhiễm. Nội dung chính của quyết định này là "khống chễ tỷ lệ bị tăng huyết áp dưới
$30 \%$ ở người trưởng thành; $40 \%$ số người bị tăng huyết áp được phát hiện".

\section{KẾT LUẬN}

Về thực trang quản lý, kết điều quả trị bệnh nhân THA: Tỉ lệ người bệnh đi tái khám không đúng lịch cũng chiếm tî lệ tương đối cao là $36,4 \%$. Tỉ lệ người bệnh dùng thuốc đúng liều và đều đặng chiếm tỉ lệ khá cao với 89,3\%. Kết cục, trong 225 bênh nhân ngoại trú chỉ có 28,9\% đạt được huyết áp mục tiêu. Một số yếu tố ảnh hưởng đến thực trạng quản lý kết quả điều trị THA: Bao gồm, các chủ trương, chính sách, quy định về quản lý và điều trị THA; nhân lực y tế phụ trách công tác. Bên cạnh đó, điều kiện kinh tế, số năm mắc bệnh, kiến thức, thái độ, thực hành phòng bệnh là những yếu tố chủ quan từ phía người bệnh có ảnh hưởng đến chất lượng công tác này.

\section{TÀl LIẸU THAM KHẢO}

1. Hội Tim mạch Việt Nam (2006) Khuyến cáo về các bệnh tim mạch \& các bệnh chuyên hóa giai đoạn (2006-2010), Hà Nôi.

2. Nguyê̂n Công Bằng (2018), Thực trang công tác quản lý điêu trị người bệnh tăng huyết ảp điêu trị ngoại trú tại Bệnh viện Đa khoa Sa Đec giai đoạn 2015 - 2017, Trường Đại học Y tế cống cộng, Hà Nội.

3. Phạm Vân Anh Nguyễn Hữu Đức, Hồ Thị Hiển, (2017), "Kiến thức, thực hành tuân thủ điều trị tăng huyết áp của hội viển câu lạc bộ bệnh nhân tăng huyêt áp bệnh viện Bạch Maii", Y học dự phòng. Tập 27, số 52017.

4. Nguyền Thị Ánh Tuyết (2019), Thực trang cầu sử dụng và cung cấp dịch vụ quản lý tăng huyết áp tại 2 xã của huyện Thông Nông, tỉnh Cao Bằng, Trường Đại học Y - Dược - ĐaỊ học Thái Nguyên, Thái Nguyền.

5. Nguyễn Thị Dự (2017), Thực trạng hoạt động quản lý bệnh Tăng huyết áp tại thành phố Hà Giang, tỉnh Hà Giang và đề xuất một số giải pháp," Đai học Y Dược Thái Nguyên, , Thái Nguyên.

6. Lể Kím Việt (2016), Đánh giá thực hiện chương trình mục tiều quốc gia về phòng chống tăng huyết áp tại thành phố Tuyên Quang năm 2016, luận văn chuyên khoa II, Đại học Y tế công cộng, Hà Nội.

7. Nguyễn Thị Đào Hương (2016), Thực trạng và một số yếu tố ảnh hưởng, đến hoạt động quản lý bệnh nhân tăng huyết áp tại xã̃ Minh Quang, hưyện Tam Đảo, tỉnh Vính Phúc năm 2016, Luận văn thạc sỹ Đại học y tế công cộng, Hà Nội.

8. A. Gimeno Ortiz và các cộng sự. (1990), "[Evaluation of salt consumption, physical activity, stress, tobacco and oral contraceptives in the epidemiology of essential hypertension]", Rev Sanid Hig Publica (Madr). 64(11-12), tr. 705-14. 